\title{
Women Thinkers and the Canon of International Thought: Recovery, Rejection, and Reconstitution
}

Canons of intellectual 'greats' anchor the history and scope of academic disciplines. Within International Relations (IR), such a canon emerged in the mid-twentieth century and is almost entirely male. Why are women thinkers absent from IR's canon? We show that it is not due to a lack of international thought, or that this thought fell outside established IR theories. Rather it is due to the gendered and racialized selection and reception of work that is deemed to be canonical. In contrast, we show what can be gained by reclaiming women's international thought through analyses of three intellectuals whose work was authoritative and influential in its own time or today. Our findings question several of the basic premises underpinning IR's existing canon and suggest the need for a new research agenda on women international thinkers as part of a fundamental re-thinking of the history and scope of the discipline.

Professor Kimberley Hutchings

School of Politics and IR

Queen Mary University of London

Mile End Road

London, UK

k.hutchings@qmul.ac.uk

+44 (0) 2078828586

\author{
Professor Patricia Owens \\ Somerville College \\ University of Oxford \\ Oxford, OX2 3UQm UK \\ patricia.owens@politics.ox.ac.uk \\ +44(0) 7913458649
}

Support for this work was provided by the Leverhulme Trust Research Project on Women and the History of International Thought (RPG-2017-319).

Canons mark out the terrain of academic disciplines by telling us about seemingly perennial discipline-defining questions and how they are addressed over time. They establish a common set of reference points for disciplinary discussion, form a core part of university curricula, and serve as a crucial pedagogic tool for the socialization of generations of scholars (Youde and Steele 2018). Within Political Science, the establishment of a canon of intellectual greats was central to the disciplinary identities of Political Theory and International Relations (IR) as they were institutionalized through the twentieth century (Gunnell 1993; Schmidt 1998). Canon formation allowed Political Theory and IR to locate themselves in a two thousand year old story in which great thinkers addressed concepts such as freedom, war, and power, exemplifying distinct 'traditions' of political or international thought that can be traced to the present day. 
The question of which thinkers constitute a particular canon is obviously important, receiving much critical attention in Political Theory and its sister discipline of Philosophy. Intellectual historians have pointed to profound methodological problems with the Political Theory canon, its criteria for inclusion and its concept of 'tradition' (Condren 1985; Tully 1989). Feminist and decolonial scholars have pointed to the marked absence of women and people of color and the attendant limitations of disciplinary thinking (Stuurman 2000). Feminist critics have been particularly active in questioning Political Theory and Philosophy, analyzing the gendered mechanisms of canon formation and attempting to address this through a variety of means (Carroll 1990; Gardner 2003; Witt 2006; Zerilli 2008; Weiss 2009; Waithe 2015; Forestal and Philips 2018; Tyson 2018).

However, little critical attention has been paid to why historical women, those working before the late twentieth-century, are absent from IR's canon of 'serious thinkers' (Luard 1992: xiii; Veregerio, 2019). In this article, we show that this is not due to a lack of international thought, or that it failed to meet the stated criteria for entry into IR's canon. Rather it is a product of the gendered and racialized politics of canon formation. We also identify resources for thinking about international relations from those excluded on gendered and/or racialized grounds. We support our claims with new quantitative and qualitative research. First, we analyze the selection criteria for inclusion in twenty-two works seeking to establish IR's canon published between 1929 and 2016. We find that the most commonly cited criteria - influence is construed in the narrowest of terms: prioritizing the influence of white men on other white men. Canonical status in IR is not a product of a neutral application of the stated selection criteria, but the gendered and racialized politics of expectations surrounding intellectual greatness and influence. These findings provide historical grounding for recent work on the ‘citation gaps' in contemporary IR (Maliniak, Powers, and Walter 2013). 
Our claim is further supported through new analyses of three intellectuals whose international thought was either authoritative and influential in its own time or is today, but who are excluded from IR's canon: the American geopolitical thinker, Ellen Churchill Semple (1863-1932); Austrian writer and Nobel Peace Prize winner, Bertha von Suttner (1843-1914); and African-American educationalist, Anna Julia Cooper (1858-1964). Cooper is not only absent from IR's canon but is completely missing from wider histories of international thought. Suttner and Semple appear fleetingly and problematically in these histories but are not discussed at length (Knutsen 1992, 1997; Hobson 2012: 108, 112, 160-161; Ashworth 2014: 100-101). We show that all three meet the stated criteria for canonical status and that their exclusion is explained by the operation of unstated gendered and/or racialized norms. These norms identify the character of work by women as derivative (excluding Semple), feminize particular modes and genres of thought (excluding Suttner), and define international relations from the standpoint of elite white men (excluding Cooper).

The article has two main sections, the first demonstrates the gendered character of IR's canon, focusing on the stated selection principles for canonical status across twenty-two works, and explains our criteria for selecting Semple, Suttner, and Cooper. The second section analyzes their international thought, examining how and why they were excluded from IR's canon, and what IR gains by taking their work seriously. The conclusion summarizes our findings, relating them to broader feminist arguments on the nature and limitations of canons in disciplinary history and pedagogy. We suggest some new research agendas that open up if IR takes seriously both feminist criticism and the work of canonical historical women. We argue that such an agenda necessitates more than (re)discovery and recovery, the inclusion of a few prominent names which leave the existing canon intact. It necessitates re-envisioning of international thought in an ongoing reconstitution of the canon of international thinkers. 


\section{The Gendered and Racialized Constitution of IR's Canon}

One of the earliest works in the history of international thought was published in 1929 by a Cambridge-trained classicist. The Growth of International Thought surveyed different strands of international thinking from the ancient Greeks to the League of Nations through an analysis of figures from Aristotle to Mazzini. The author was popularizing liberal internationalist ideas, but the approach of surveying canonical thinkers was later adapted by those seeking to establish IR as a discipline from the early 1950s (Morgenthau and Thompson 1950; Wolfers and Martin 1956). ${ }^{1}$ Largely for pedagogical purposes, hundreds of thinkers and their main works were collected in anthologies and analyzed in edited volumes. Such studies formed the basis of the many eponymous schools of IR theory: Hobbesian, Lockean, Kantian, and so on.

The author of The Growth of International Thought, the first of this genre, was not Alfred Zimmern, Gilbert Murray or Arnold Toynbee, all well-known classical scholars in IR's intellectual history. It was Florence Melian Stawell. Unknown to later students of IR, she inaugurated a genre - surveys of 'men of large and capacious thought' (Thompson 1980: ix) from which she and numerous other women were effectively barred. More generally, very few works of international theory center on historical women (Owens, 2007; Hutchings 2009; Hansen, 2011; Kinsella 2014; Cochran 2017). This is mirrored in the small number of studies on the foundational role that women played in the field of international relations from the early twentieth-century (Sluga 2017; Stöckmann 2017; Owens, 2018; Huber, Pietsch, and Rietzler 2019; Owens and Rietzler 2021; Owens, Rietzler, Hutchings, Dunstan, 2021).

On what basis, with what stated criteria, do authors and editors select canonic thinkers and texts? We examined the rationale in twenty-two works published in English between 1929

\footnotetext{
${ }^{1}$ The subject of International Relations was taught in university departments before the 1950s, but the discipline, with its own professional associations, was not formed until after World War II.
} 
and 2016, covering the full spectrum of IR approaches, both mainstream and 'critical'. ${ }^{2}$ Four works provided no explicit discussion of the selection principles (Stawell 1929; Clark and Neumann 1996; Jahn 2006; Roache 2008). Of the remaining, by far the most commonly stated criterion was 'influence', receiving thirteen references when 'significance' and 'importance' are counted as proxies. ${ }^{3}$ 'Representativeness' received five mentions, with 'variety' as a proxy. ${ }^{4}$ The 'quality' or 'greatness' of the thinkers and/or their works were cited on four occasions (Thompson 1980; Thompson 1994; Vasquez 1995; Brown et. al. 2002) and their 'centrality' (Thompson 1980; Kauppi and Viotti 1992; Long and Wilson 1995) and coverage of 'recurrent themes' were each mentioned three times (Forsyth et. al. 1970; Vasquez 1995; Brown, Nardin, Rengger 2002). 'Comprehensiveness'/breadth was mentioned twice (Luard 1992; Lebow et. al. 2016). One volume referred to the practical consideration of the length and accessibility of texts (Forsyth et. al. 1970), and one to the authors' personal closeness 'to the men themselves' (Thompson 1980: xi).

Across all twenty-two works, there are 572 cumulative references to all historical figures. Of these, there are nine references to women: $1.57 \%$. This translates to six historical women with some recognition as significant thinkers: Susan Strange, Hannah Arendt, Simone de Beauvoir, Margaret Mead, Susan Sontag, and Virginia Woolf. ${ }^{5}$ With one exception, all collections that include these figures were published after 2009 and there are never more than two in the same volume. IR's 'critical theory' collections are slightly better than the 'traditional' canon, claiming three volumes that include two historical women (Edkins and

\footnotetext{
${ }^{2}$ In doing so, we update and expand the eighteen texts analyzed by Owens (2018), adding Clinton (2003), Wight (2004), van de Haar (2009) and Elman (2014) and include, for the first time, an analysis of the criteria for selection.

${ }^{3}$ Wolfers and Martin 1956; Thompson 1980; Thompson 1994; Kauppi and Viotti 1992; Luard 1992; Williams, Wright, and Evans 1993; Long and Wilson 1995; Brown, Nardin, Rengger 2002; Edwin van de Haar 2009; Edkins and Vaughan-Williams 2009; Moore and Farrands 2010; Bliddal et. al. 2013; Lebow et. al. 2016

${ }^{4}$ For representativeness see Kauppi and Viotti 1992; Clinton 2003; Wight 2004; van de Haar 2009; Elman 2014

${ }^{5}$ We exclude a very brief reference to the biblical figure of Ruth in Stawell (1929), in which Ruth is taken to foreshadow a liberal internationalist 'charm of foreign culture' (1929: 31).
} 
Vaughn-Williams 2009; Moore and Farrands 2010; Lebow et. al. 2016; but Roache (2008) includes none).

These findings suggest that generations of IR authors and editors, critical or otherwise, have interpreted the selection criterion of influence, comprehensiveness, representativeness, quality, and recurrent themes to effectively exclude women from its canon. To understand how the choice and interpretation of the criteria could yield this result we examined in more detail the most common criterion: influence.

We found surprisingly little, if any, elaboration of what influence means when authors explained this criterion. For example, Williams, Wright, and Evans (1993: 8) suggested that a large number of texts are simply 'self-selecting because their authors are well established as important thinkers'. Wilson chose thinkers who 'were regarded as leading experts... by the various political, research, and policy bodies with which they were closely associated' (1995: 19). Thompson added more detail, noting that 'Important writers often tend to generate controversy, open new sectors of inquiry, contribute "breakthroughs" in thought, have a formative influence, and enjoy successive revivals of interest' (1980: x). Yet there is no discussion of the means through which influence is felt and on whom, the temporality and politics of influence, or the circularity and recursive nature of such claims.

In the one volume that did offer an additional elucidation, 'canonical status represents a judgement about the quality of... thought' (Brown et. al. 2002: 3, emphasis added). Influence is a proxy for excellence. On this basis, the editors explain why no women were among their fifty thinkers; the only explicit attempt to justify this exclusion that we found. In their words,

Because the relevant criteria can change on the basis of current fashions... the fact that all the writers... are white male Europeans might, or might not, be regarded a legitimate criticism. Nonetheless, ... [s]ome thinkers clearly have produced more significant work than others and it seems right that this should be recognized in an informal way, always assuming that the canon is never fixed once and for all (2002: 3). 
Women were excluded from the largest collection of international thought then available because they wrote nothing of significance. Women's thought is not significant or influential because it lacks quality.

The rest of this article demonstrates that this claim is false. The stated criteria for canonic status reproduce gendered and racialized exclusions not by chance, or due to the intellectual failings of women and people of color. It is due to the unstated meanings attached to the selection criteria. These encode understandings of quality or influence that systematically privilege those gendered as male and racialized as white. Our findings confirm the feminist historiography in other fields: historical women's exclusion is more than accidental; it is constitutive (Carroll 1990; Smith and Carroll 2000; Smith 2007). This literature also suggests a variety of responses to the gendered and racialized formation of IR's canon. These include exposing the processes through which diverse historical women were marginalized (Gardner 2003; Weiss 2009; Philips 2018; Tyson 2018); recovering and analyzing women's thought (Gardner 2003; Ménage 1984; Waithe 1987-1995; McAlister 1996; Broad and Green 2009; Weiss 2009; Green 2014; Bay et. al. 2015; Blain and Gill 2019); and reconstituting, or moving beyond, the disciplinary canon itself (Pollock 1999; Stuurman 2000; Waithe 2015; Forestal and Philips 2018; Tyson 2018).

We now extend each of these responses to IR with analysis of the international thought of three figures who easily meet the stated criteria for inclusion in IR's canon. First, however, we say more about our category of 'canonical woman international thinker' and our own criteria for selecting Semple, Suttner, and Cooper.

International thinking is reflection on the relations between peoples, empires and states, a broad understanding consistent with IR's existing canon and disciplinary history (Schmidt 1998; Vitalis 2015). By 'women' we refer to the discursive, intersectional and historical construct emergent from the sex/gender and male/female binaries, which assume biologically 
distinct 'men' and 'women' (on intersectionality see Crenshaw 1989). To speak of historical women does not commit us to gender essentialism or a correspondence between biology and gender identity. At stake in presenting our thinkers as women is recognition of the effects of the operation of the male/female binary on the content and reception of their work, and, indeed, on all international thought. Each of our thinkers explicitly reflected on their identity as women. They also explicitly reflected on race and their intellectual production was shaped by their racialized as well as gendered positions; but only one was marginalized from IR's canon on racist grounds.

Given the large and growing scholarship on women's philosophical, social, and political thought we were already familiar with a relatively large number of historical, selfidentified women with a claim to canonical status (Ménage 1984; Waithe 1987-1995; McAlister 1996; Smith and Carroll 2000; Weiss 2009; Broad and Green 2009; Green 2014). Rather than selecting our thinkers from the more remote past, we focused on those active during the late nineteenth- and early twentieth centuries, when the interdisciplinary field of international relations emerged and the immediate prehistory of the later consolidation of the separate academic discipline of IR from the 1950s. For this reason, it is also the focus of recent revisionist history (Knutsen 2014; Ashworth 2014; Vitalis 2015; Thakur and Vale 2020). In fact, in this pre-disciplinary era, there was a greater openness to women intellectuals and teachers of international relations than in IR's later 'disciplinary' phase during which IR's canon was constructed and earlier generations of women were erased from its intellectual and disciplinary history (Sluga 2017; Owens and Rietzler 2021; Owens, Rietzler, Hutchings, Dunstan 2021). In terms of geographical location, we focused on Europe and North America given the United States' dominance in IR but also the influence of European intellectual traditions. This focus constrains our geographical and linguistic scope. But we have chosen to 
test our assumptions on the basic predicates and focus of IR itself, even as we disagree with them.

Within this remit - canonical women working in Europe and the United States between the late nineteenth- and early twentieth-century - we consulted the published scholarship and secondary literature on figures that we knew had written on international relations but whose writings on this subject had not been systematically investigated in literature on their thought. Our initial list included Germaine de Staël, Bertha von Suttner, Anna Julia Cooper, Ellen Churchill Semple, Jane Addams, Emma Goldman, Rosa Luxemburg, Sylvia Pankhurst, Virginia Woolf, Hannah Arendt, Rebecca West, Simone Weil, Simone de Beauvoir, Amy Ashwood Garvey, Eslanda Robeson, and Ayn Rand. Of these, there are three main categories from which we could have selected: those that could have been included in IR's key 'isms'/'traditions' yet were not; those who could not fit; and the few already accorded partial recognition. We excluded this third category, because a case had already been made for their (limited) inclusion (Owens, 2007; Hutchings 2009; Wilson, 2013; Kinsella 2014). However, within each of the other two categories we wanted a diversity of views, texts, genres and professional and national contexts. Hence, we selected the American geopolitical academic Ellen Churchill Semple, the Austrian liberal internationalist author Bertha von Suttner, and African-American internationalist scholar Anna Julia Cooper.

\section{In and Beyond the Canon: Semple, Suttner and Cooper}

We now proceed to analyze Semple's, Suttner's and Cooper's international thought. We demonstrate that in all three cases, their exclusion from IR's canon reflects unstated gendered and racialized selection criteria. Looking carefully at these mechanisms not only helps us understand how the IR canon has excluded historical women, but also to reflect on the nature 
and contribution of each thinker, and the varying degree to which their work challenges the embedded assumptions of IR's canon.

Ellen Churchill Semple (1863-1932)

Ellen Churchill Semple developed one of the earliest and most comprehensive theories of the geographical shaping of international politics in the twentieth century. Her work is important because it offers insights into the history of international thought on state-building, civilization, race, colonialism, and technology, but also because of its influence across Anglophone Geography, IR, History and Political Economy in the first half of the twentieth century. Here we set out the originality and significance of Semple's ideas and demonstrate the gendered reception of her work which precluded her admittance to IR's canon.

The geopolitical tradition played a central role in the intellectual development of IR as a distinctive field (Ashworth 2014). Semple was known for pioneering ideas about geography and international politics, which were a major focus of debates in History and the emerging disciplines of Geography, Politics and IR (Koelsch 2014). Her work is part of a distinctively Lamarckian thread of thinking about human evolution in which spatial environments shape hereditary characteristics. This privileged the role of environment in explaining historical change and human differentiation. Semple's work is distinguished by the detail and complexity of her account of the environmental factors operating in history, and how she drew on this complexity to explain international phenomena including trade, war and colonialism.

In an early rehearsal of arguments made throughout her work, Semple characterized humans as 'shifting, plastic, progressive, retrogressive' in contrast to the permanence of the geographic environment. In her words,

Man is a product of the earth surface. This means not merely that he is a child of the earth, dust of her dust; but that the earth has mothered him, fed him, set him tasks, 
directed his thoughts, confronted him with difficulties that have strengthened his body and sharpened his wits, given him his problems of navigation or irrigation... She has entered into his bone and tissue, into his mind and soul (1909, 422-3).

With explicitly gendered language, Semple explained human diversity and political organization as an outcome of the effects of different geographical factors, which vary from climate to landscape. This was not a simple linear process, but one in which multiple factors crosscut and stimulated different responses in an unpredictable process.

Semple's arguments disturb straightforward distinctions between 'idealist' and 'realist' discourses in this period (Ashworth 2014). On the one hand, Semple celebrated historical progress, the globalization of trade, the development of ideals of freedom and democracy. On the other, she located these developments firmly in the effects of geographical factors on particular 'peoples', and exemplified highly influential evolutionary, racist and Eurocentric ideas. Not unlike her contemporary, F. Melian Stawell, Semple viewed the Mediterranean region and colonial expansion as the ultimate origin of progressive civilization. Their racism was in accord with most IR scholarship at the time. 'All the world is heir of the Mediterranean' (Semple 1932: 3). Africa was 'a poor mediator, limited in its power either to give or to receive'. Semple commended an earlier tendency to view Egypt as part of Asia; while geographically mistaken, she argued that it was correct on civilizational grounds (1932: 6; Semple 2011, 158). For Semple, the impetus to colonization was the desire and ability to overcome and escape geographical limitation. War or famine, arising out of over-population or lack of resources, drove people to find new settlements; levels of group interaction and the spread of superior cultures then followed. This was not just Semple's view in relation to the ancient Mediterranean. She was deeply interested in colonization as a source of progress across the world, as crucial to civilizational development. She offered advice to Japan on the colonization of Korea, castigating the government for cramping 'the natural and healthy colonizing instincts of the people' (1913, 263-4). Her argument was straightforwardly prescriptive, supporting 
colonial Japan's efforts to regenerate the 'docile, amiable, lazy, ineffectual' Koreans (2013, 267; 273). Semple congratulated Japanese leaders on their grasp of pacification war on insurgent 'savages' in Formosa, of not only seeking to improve health and welfare, but through gathering knowledge of tribal peoples (Semple 2013, 273).

Unlike many other women thinkers of her generation, Semple had a professional profile and a series of university positions, including the Presidency of the American Geographical Society. She directly experienced gender discrimination, including inequities in pay (Berman 1974). Yet in an early 1882 address, she suggested that her field was,

particularly suited to women because of their natural endowment, - their power of observation, their capacity for detail work, their patient perseverance in the collection of material, their intellectual humility, which makes for cautious induction, and finally their imagination (quoted in Bushong 1975, 104)

While clearly reflecting the gendered stereotypes of Semple's time, this statement also points to how white, educated middle class women in the United States could create a permissive space for intellectual work. In Semple's case, this included extensive fieldwork in which the privileges inherent in being a white middle class woman in an imperial world order, enabled her to research local contexts and populations abroad, and to report her findings to an appreciative audience back home (Adams 2014).

Unsurprisingly, Semple's (1911) major work, Influences of Geographic Environment on the Basis of Ratzel's System of Anthropo-Geography, was reviewed in the first IR journal, The Journal of Race Development. Although Semple's ideas were always contested, as were those of other geopolitical thinkers, her works remained required reading on geography curricula until the 1940s, one of the key modes in which international relations was studied prior to World War Two (Keighren 2010, 119-173). As Bushong notes, 'Most of the second generation of modern American professional geographers were her students' $(1984,88)$. Semple's disciples populated academic positions and taught in schools across the United States (Keighren 2010, 129). Her ideas were transmitted to IR through her exchanges with 
contemporary geopolitical thinkers (such as Mackinder), students (such as Whittlesey) and critics (such as Bowman). Her arguments were a constituent part of the geopolitical thinking that influenced international policy in the Anglophone world in the early twentieth century (Black 2016). She was one of the academic experts in the 1917 'Inquiry', forerunner of the Council of Foreign Relations, developing proposals for the boundaries of new nations for the Paris Peace negotiations; her resultant briefings were read by Woodrow Wilson at Versailles (Keighren 2010,139).

Given the originality and influence of Semple's work on one of IR's core subjects why is she excluded from its canon? It cannot be due to the post-1945 expurgation of geopolitics in Anglophone IR given its association with Hitler's world policy. After all, IR's canon includes Spykman (Thompson, 1980), Mackinder (Luard 1992) and Mahan (Wolfers and Martin 1956; Luard 1992). Typically, Semple's male predecessors (Ratzel, Mahan), her contemporaries (Mackinder, Haushofer), and her successors (Bowman, Whittlesey) are also more prominent in wider literature on geopolitics (Agnew 2003; Chapman 2011; Dodds 2014; Fettweis 2015) and histories of international thought (Ashworth 2010; 2013 Hobson 2012; Knutsen 2014). Indeed, this neglect continues in recent work on IR's history. In McCourt's account of the relation between the 1917 Inquiry and disciplinary IR we are told that no women participated at all $(2017,400)$. In fact, not only Semple but twenty-eight women are listed in the salary records and personnel returns for the Inquiry in 1918, including area experts, diplomatic historians, economists and experts on international law (Gelfand 1963: 337-343). It would be difficult to believe on the basis of Ashworth's discussion $(2013,139-40)$ that the Head of Research 'urged [Semple] to break any engagement and drop all other work to contribute to the business of the Inquiry' (Keighren 2010, 138).

In wider histories of international thought, if she appears at all, Semple is almost invariably introduced as the student or pupil of the German thinker Friedrich Ratzel, with 
whom she studied. For Hobson, Semple is Ratzel's 'disciple', the only use of this marker in a discussion of over one hundred other figures $(2012,261)$. Semple either simply channeled Ratzel's thought for Anglophones or got Ratzel wrong. According to Ashworth (2014: 100),

Semple claimed to be introducing Ratzel's political geography to an American audience, but in fact her interpretations glossed over Ratzel's distinctions between environmental determinism and agency to produce an approach to political geography that was fundamentally and explicitly environmentally determinist.

Such claims neglect Semple's own account of her relation to Ratzel; treat Influences in isolation from her earlier and later work; and misconstrue her relation to environmental determinism. Semple is mistakenly reduced to a more or less effective mediator of Ratzel's ideas, as opposed to a thinker in her own right. In contrast, Bowman and Whittlesey, both of whom learned from Semple, appear as independent thinkers (Ashworth 2013; c.f. Ashworth 2011, 2020).

In fact, Semple explicitly rejected Ratzel's organicist state theory, and regarded his approach as underdeveloped in significant ways (1911: vi). Geographers remain divided about the degree and nature of Semple's determinism, with some perceiving agency as more significant in her pre-1911 writings (Hawley 1968). Others view her determinism as softening in line with wider intellectual developments after World War I (Koelsch 2014). As she put it, 'The eternal flux of Nature... warns against precipitate or rigid conclusions... For this reason the writer speaks of geographic factors and influences, shuns the word geographic determinant, and speaks with extreme caution of geographic control' (1911: vii). Paying attention to Semple in her own right disturbs simple accounts of her 'determinism'. It resituates Influences as one important work in a considerable oeuvre; allows consideration of Semple's own grasp of issues of causation and complexity; and allows her international thought to shift across time.

While we cannot do justice to its full range, Semple's ideas about territory, colonialism and race were a crucial element of the international thinking that shaped the theory and practice of early twentieth-century world politics. Her exclusion from IR's canon is thus particularly 
surprising, given the degree and range of her influence in the period in which IR traditionally located the proximate roots of its main intellectual traditions. In accounting for her absence, it is not difficult to observe the gendered reception of Semple's work. We have also seen that in the few brief engagements with Semple in wider intellectual and disciplinary histories, her marginalization is due to a persistent tendency to deny independent meaning to her ideas and to place them as immediately superseded by later generations (for a rare exception see Black 2016). That women's intellectual contributions are dismissed as simply echoing those of men is well-documented in feminist work (Russ 1983; Weiss 2009). Men acknowledging an influence, even of someone who mediates others' ideas, can still be addressed as significant thinkers. Yet as with Sartre and Beauvoir so with Semple and Ratzel, because she acknowledged his influence, she is not a thinker of independence, importance, and influence, the stated criteria for inclusion in IR's canon.

\section{Bertha Von Suttner (1843-1914)}

Like Semple, but to an even greater degree, Bertha von Suttner's work possessed extraordinary influence during the period in which international relations emerged as a distinct field (von Suttner 1894; 1910a; 1910b; 1914; 2016). During the late nineteenth and early twentieth centuries, Suttner was a crucial originator and disseminator of liberal pacifist ideas among international activists, practitioners and the general public, especially in the context of the 1899 and 1907 Hague conventions. In 1905, Suttner was the first woman solely awarded the Nobel Peace Prize. Her arguments were important for the development of international law as an instrument of liberal pacification (Peter 2012: 1142-1145). Suttner prefigured inter-war thinkers such as Salter and Keynes, arguing for the unification of Europe, recognized by the European Union itself (European Economic and Social Committee 2012). Her ideas also fed 
into strands of feminist pacifism articulated at the 1915 Women's Conference at The Hague, the origin of the Women's International League for Peace and Freedom.

Suttner's international thought is undoubtedly part of what later IR scholars have defined as liberal internationalism or idealism, and more recently analyzed as an evolutionary, Eurocentric and civilizational discourse (Knutsen 1992; Hobson 2012). Unlike Semple, she opposed colonialism. Yet like her, Suttner deployed the language of civilization and barbarism. She thought it was particularly shameful that Europe could still indulge in war at the start of the twentieth century because, unlike other civilizations or regions, Europe should know better. Suttner engaged with environmental and evolutionary texts, such as Buckle's (1872) History of Civilization in England which also influenced Semple. Buckle explained the trend of world history towards European dominance in terms of the moral and intellectual characteristics of the Enlightenment, the triumph of reason over superstition, humanity over nature. Suttner made her argument against war in this context. War was regressive and 'barbaric', a lapse back to a nature out of tune with the humanistic and progressive movement of world history.

However, what makes Suttner's international thought distinctive is not her pacifism and internationalism, Eurocentrism or racism, but her treatment of war, nationalism and militarism. Suttner pioneered arguments commonly articulated in the early twentieth century by canonized ‘idealists' such as Angell (Luard 1992; Long and Wilson 1995; Bliddal et. al. 2013; Lebow et. al. 2016). Modern warfare, she argued, was self-defeating in the light of modern technologies and processes now understood as 'globalization'. She was skeptical of the logic of deterrence, saw public opinion as a force that could be mobilized against war, and advocated the potential of legal regulation to replace war in settling disputes. Each of these contributions justifies Suttner's inclusion in IR's canon.

In this regard, Suttner's most original thinking was her attention to the ideologies and micro-practices that sustained war. She prefigured much later Gender Studies work on how 
children's toys and books, and masculinity rituals such as dueling, were part of a world in which 'To be exposed to murdering and being murdered was simply one of the chivalric and patriotic necessities that life brings to man' (1910a, 138). Suttner's analysis of the complex relations that enabled war made her highly critical of contemporary efforts to 'humanize' war, for example through regulation of weapons, or use of defensive, deterrent technologies (1910b: 100; 228-9). She was furious when Dunant, founder of the Red Cross, received the Nobel Peace Prize (1910b: 292), and when successive peace conferences were hijacked by those seeking to regulate rather than abolish war (1910b: 228-9). In her words, 'The securing and organizing of peace have nothing to do with the regulation of war... - quite the contrary! ... They are driving in the wedge that shall split the work of peace' (1910b: 286). Attempts to ameliorate war simply helped to perpetuate it; war could no more be humanized than slavery or torture (1910b: 2867).

In this respect, Suttner was highly skeptical of claims regarding 'clean' weapons or weapons that would never be used. In novels and pamphlets written in the five years before her death, Suttner focused on the dangers of aerial warfare $(1914 ; 2016)$. This followed the failure to ratify the agreement to ban aerial bombardment at the 1907 Hague Conference, demonstrating the limitations of legal regulation. Suttner's later work lost some of the strong optimism of her 1889 novel Lay Down Your Arms, which diplomatic historian Merze Tate described as 'perhaps the greatest peace novel of all times' (1942: 53). At one level, Suttner remained wedded to the idea that scientific advances were essential to human progress and eventual peace. But she had identified a fundamental paradox; the technologies that enable communication and render borders and distance insignificant, thus part of the march of progress, were always recouped for military purpose (1910b: 401; 2016).

Merze Tate's engagement with Suttner in The Disarmament Illusion (1942) tells us something of the gendered reception of Suttner's work in disciplinary IR, as well as the 
gendered and racialized reception of Tate (Vitalis 2015). Tate's first book analyzed the early twentieth-century efforts to reduce armament production and thus necessarily engaged with Suttner. But as Herren has observed, when she 'highlighted... the role of the many women's organizations active at the Hague Peace Conferences' this aspect of her otherwise celebrated work 'evoked critical reviews' (2016: 191). Still, decades later, when Suttner appears in lists of liberal pacifists, it is her male peers who are analyzed. For example, Hobson includes Suttner among the liberal Darwinists and pacifist Eugenicists, but does not discuss her work, subsuming it under categories of colonialism and racism which conceal her active opposition to colonial wars and to Antisemitism. Knutsen cites Roger Chickering's belittling of the Peace Society that Suttner had established in 1891: 'a comical sewing bee composed of sentimental aunts of both sexes' (1997: 212).

Suttner was used to being mocked and would not have been surprised by her reception in contemporary IR. As a public intellectual, peace activist, novelist, and woman, her work was constantly ridiculed. For those who approved of Suttner's international thinking, her gendered identity empowered her critique of war. For those who disapproved, it spoke precisely to her inability to engage rationally with the world of high politics. Crucially, in addition to her gender, Suttner's use of literary form is another reason to dismiss her significance. The reception of intellectual work is shaped by conceptions about the most appropriate way to express serious ideas: linear arguments that are neutral in tone, not partisan and flowery, that rely on reason, not emotion. Suttner's writings do not meet this masculinized bar, at least not consistently. Yet these are reasons to take her arguments more not less seriously. Suttner understood the power of fiction, especially autobiographical fiction, as a vehicle for the communication of political ideas. As she wrote,

In treatises one can only lay down abstract appeals to the reason, can philosophize, argue and dissertate; but I wanted something else: I wanted to be able to put into my book not only what I thought but what I felt, felt passionately; I wanted to give expression to the pain which the image of war burned into my soul; I wanted to present 
life, palpitating life, reality, historical reality; and all this could be done only in a novel, and best in a novel written in the form of an autobiography (Suttner 1910a: 294-5).

Suttner leveraged her feminized persona and her class position to gain a platform to make the powerful arguments in Lay Down Your Arms, one of the most important and influential literary works on war in the first half of the twentieth century.

Martha von Tilling, the protagonist of Lay Down Your Arms and its sequel Martha's Kinder (1903), is clearly Suttner's aristocratic feminine avatar. She is comically hopeless at doing anything constructive in a war zone, unlike the competent nursing nun she accompanies. But war is not something that can be ameliorated by the efforts of heroic nuns. Martha's incapacity in the face of war's horrors is the right response because it can only issue in an absolute rejection of war and its conditions of possibility. Her aristocratic uselessness and feminine sensibility combine to enable her to see the absurdity as well as the horror of war but also how militarism is embedded in society as a whole, including in gendered divisions of labor. Lay Down Your Arms exposes how emotional investment in war is manipulated, spiritually elevated through a gendered economy of sacrifice. 'Next to the blood which soldiers pour out on the altar of their country, the tears which bereaved mothers, wives, and sweethearts of the soldiers pour on the same altar become a libation hardly less sacred' (1894: 40). Martha initially took for granted the tropes of patriotism, the glory of war and the beauty of sacrifice. But through her own experience of bereavement, motherhood, and self-education, she 'recognized too soon that the desire for battle was not a super-human but an infra-human feeling, no mystic revelation from the realms of the morning, but a reminiscence of the realm of the animal, a re-awakening of the brutal' (1894: 157).

Although Suttner was a firm supporter of women's rights and highly conscious of the importance of gender in reproducing war, she identified as a humanist not a feminist. She was not an academic in the mold of Semple or Cooper. Like many of the liberal intellectuals of her 
time she worked in the public domain of journalism and propaganda. However, unlike most of these intellectuals, her work was known to an international audience of hundreds of thousands. Her ideas were key to peace organizations across Europe and the United States from the 1880s until her death in 1914. No history of pacifism can be written without reference to her, and yet Suttner is missing from IR's canon, a field some have argued was conceived precisely to understand and achieve peace (Olson and Groom 1991; c.f. Vitalis 2015).

Comparing Semple and Suttner illustrates how the unstated criteria for inclusion in IR's canon are operationalized in different ways, and vary depending on the degree to which they challenged the canon's core assumptions. Semple is challenging primarily because she is a woman. She is easy to overlook because women's academic work is assumed to be derivative. Yet, at the same time, her work is fundamentally consistent with dominant norms about the content and method of international thought. Semple was an academic, her work was Eurocentric and racist, and she was deeply embedded in a community of geopolitical theorists, many of whom were afforded canonic status. If Semple had been included in IR's canon, perhaps as a token woman, then IR's self-understanding would not have changed a great deal.

Suttner, in contrast, challenges IR's canon in different ways. She was doubly excluded through being doubly feminized. First, she could be construed as not 'serious': unsystematic and inconsistent, 'comical' and 'sentimental' given her focus on emotions. Such traits, some of which are glossed in treatments of male thinkers like Rousseau, become reasons for her exclusion. Second, she wrote from an explicitly feminized standpoint, in the first person, in genres such as novels. It is not unusual for public intellectuals to work across genres. In her lifetime, Suttner's novels were taken seriously as international thought, like those of W.E.B. Du Bois or H.G. Wells, but not in the construction of IR's canon. Figures primarily known for journalistic and fictional work were marginalized, an exclusion that is only now being challenged in IR, to date on behalf of men (Bell 2018). Here we see how gendered assumptions 
bite deeply not only into attitudes towards women scholars, but into assumptions about the substance and form of what counts as international thought (Gardner 2003). Compared to Semple, Suttner does more to upset IR's canon. She challenges what it means to be an international thinker and opens up new categories and possibilities for international thought.

Anna Julia Cooper (1858-1964)

Examining Anna Julia Cooper's work in comparison to Semple and Suttner casts further light on the gendered and racialized assumptions that shape the construction of IR's canon. In offering a more profound challenge than either Suttner or Semple, Cooper also offers a vision for an alternative account of what international relations is and what might count as international thought. Like Semple, Cooper was an academic, an educator and a systematic thinker. Like Suttner, she saw the analytic and normative potential of women's 'voice'. Like both, she used a language of civilization and progress. But her understanding of the nature of world politics, and what it means to think about world politics, were radically different.

Concepts of race, civilization and evolution were central to understanding international relations in the early twentieth century. Typically for their time, Semple and Suttner embedded racist and civilizational distinctions and hierarchies into their thinking and took for granted that the location of international relations was the high politics of white elites steering inter-state and inter-imperial relations. Widespread concerns about multi-racial states focused on threats to the 'health' and productivity of 'inferior' peoples. 'Race' was understood to be determined by biology, culture or environment, that is, outside the international arena (Vitalis 2015). In contrast, Cooper analyzed colonialism, imperialism, revolution and capitalism as produced and sustained by a globally transversal politics of slave-based economies, racialization, and 
feminization. International orders were produced through racialized and patriarchal property relations (1988a [1925]).

Cooper understood her own position as thoroughly internationalized. She was a Black, American, Christian, educated woman, who had been born into slavery, part of a transnational African diaspora (Pellow 1997). Consideration of this positionality was the basis for a distinctive standpoint from which Cooper analyzed national and international orders, as well as practiced internationalist, anti-discriminatory politics. For her, international relations could not be understood in distinction from national politics because they permeated each other. Both national and international orders were the product of interconnected power structures and relations of caste and property. Cooper repeatedly returned to these claims in her groundbreaking 1925 Sorbonne doctoral thesis, translated as Slavery and the French Revolutionists.

In this work, Cooper analyzed the interaction between identities and interests in her historical analysis of the relations between French revolutionary regimes and ideologies, their slave holding colonies, and the successive revolts of colonialists and slaves in what became Haiti. Both identities and interests were causally significant in the revolutionary authority's ambivalence about emancipation, and in the refusal of white plantation owners to give up their property and status. They were equally significant for the actions and reactions of free and enslaved Blacks. Exploring the intersection of economic structures and racialization, Cooper sought to demonstrate how sophisticated racialized distinctions were a form of governance that left deep and counter-intuitive legacies. In her words,

And these color prejudices, rightly abhorred by 'philanthropists', were easier to hate in theory when one did not live in the places where they had been perpetuated for centuries, and when one knew nothing of the life of the colonies where they had grown so deep that they were even stronger than all other social distinctions... to the point where a mulatto slave would have refused to obey a free Negro, even if the latter has the audacity to buy him (1988a, 158-9). 
These interests and identities are not reducible to the terms of high politics; they cut across existential, parochial, national and imperial locations.

As Vivian May (2007: 110) points out, Cooper's doctoral work preceded by a decade C.L.R. James's (1938/1963) more famous treatment of the Haitian Revolution, The Black Jacobins, which does not reference Cooper. Here, the significance of gendered as well as racial dynamics in the publication and reception of Cooper's work come to the fore. Although academically trained, Cooper spent much of her working life teaching in segregated schools. She completed her PhD in her sixties in the teeth of opposition from her employer. She did not have the networks to get an academic press to publish her thesis, nor the time and resources to do it herself. However, in the 1940s, she privately published a booklet, 'The Third Step', which included the speech she gave upon receiving her diploma and written versions of oral responses to questions from her oral defense (Lemert and Bhan 1998, chapters 24; 25; 27). She also passed her dissertation for translation and publication to her friend, Alfred Vance Churchill. In the 1940s, Churchill passed on a copy to Leona Gabel, a colleague at Smith College, who worked for many years on a Cooper biography (Gabel 1982). Frances Richardson Keller, a French Studies scholar, eventually translated to English and published the dissertation in 1988, more the sixty years after it was defended. Although Cooper scholars recognize the importance of the work, the text remains little known to this day outside this readership (Richardson Keller 1975; Gabel 1982; Pellow 1997; May 2007).

Throughout her life, Cooper's writing had to fit alongside full-time teaching and administrative posts and caring for several adopted children. She famously complained that the Pan-African conventions were held during teaching term or in places that those with limited funds could not reach. Her personal experiences of intersectional hierarchy were fundamental to her earlier, most famous work, A Voice from the South, originally published in 1892 (Cooper 1988b). This work contains Cooper's distinctive methodology and account of the intersection 
of gender, race, class and international politics from the standpoint of a Black woman. It contains acute analyses of how modes of hierarchical group differentiation become entrenched and reproduced through the interaction of interests and identities. For Cooper, caste distinctions that justify oppression also construct political interests and tools for their advancement. Property owners gain an interest in keeping Black tenants out if the value of their property declines when rented to people of color (1988b: 251). White feminists gain an interest in stressing their racial superiority as leverage in debates about the franchise, claiming superiority over Indians and Negroes (1988b: 118; 124); and Black men 'seem thoroughly abreast of the times on almost every other subject, [but] when they strike the woman question, they drop back into sixteenth century logic' (1988b: 75). In this complex of gender, race, class and international hierarchies, Black women were the group most silenced and excluded, but with much to say.

In speaking from the standpoint of a Black woman, Cooper turned what can be used to stabilize a false sense of superiority into a resource for thought. In her $\mathrm{PhD}$ examination, Cooper was asked to respond directly to one of her examiners, Célestin Bouglé, a white supremacist. In ways similar to Semple, Bouglé restricted the capacity for democracy to the 'Nordic' peoples, who had the responsibility of ruling other races. Cooper showed how Bouglé's interests and identity were bound up with his civilizational narrative, offering him simultaneous power and pride. In an unequivocal response to the claim of racial superiority, Cooper responded, 'The concept of Equality as it is the genuine product of the idea of inherent value in the individual derived from the essential worth of Humanity must be before all else unquestionably of universal application' (1998: 297; May 2007: 98-100)

Cooper did not conceive of the standpoint of a Black woman as parochial and exclusive but able to grasp the true complexity of relations of domination. It could also expose the selfdefeating competitions over different forms and degrees of oppression. For her, if the women's 
movement was dedicated to the cause of freedom, then it was entirely contradictory to differentiate women's freedom from other freedoms. 'Why should woman become a plaintiff in a suit versus the Indian, or the Negro or any other race or class who have been crushed under the iron heel of Anglo-Saxon power?' (1988b: 122). Here Cooper prefigured feminism as a transnational political project; ongoing struggles over the category of 'women'; and their translation into practices in international policies around gender and development.

Cooper championed individual equality and freedom. But this was not the onward march of triumphant liberalism, in which equality can be interpreted as sameness. Her commitment to the infinite value of the individual was tied to her recognition of the significance of perspective, for our ability to perceive ourselves or others as free and worthy of respect. She recommended a commitment to plurality, in which men and women of all races, classes, and nations could enlighten each other about the meaning of freedom and equality inherent in their experience. 'The supremacy of one race, - the despotism of a class or the tyranny of an individual cannot ultimately prevail on a continent held in equilibrium by such conflicting forces and by so many and such strong fibred races as there are struggling on this soil' (Cooper 1988b, 167). Pluralism was a prerequisite for the achievement of justice in the context of multiplicity and hierarchy, the defining characteristic of international politics. It also reflected Cooper's view that the 'domestic' relations of the United States were as international as the imperial relations of the French revolutionary regime with its colonial possessions and postcolonial successors.

Cooper was not unknown in her own time. She spoke at the first Pan-African Congress Conference in London in 1900 and was in correspondence with and cited (without being credited) by W.E.B. Du Bois (Moody-Turner 2009, 7; James 2007; May 2007). Nevertheless, even in her own time, Du Bois and C. L. R. James gained greater recognition. Retrospectively she has been identified as a founding figure for Black Feminism, Africana and Diaspora Studies 
(Guy-Sheftall 2009; Moody-Turner and Stewart, 2009; Pellow 1997). But she has not been incorporated into the IR canon, even as race and colonialism have become more central to contemporary work in IR (Vitalis 2015; Anievas et al 2014). In comparison to Semple and Suttner, Cooper's work is not even mentioned dismissively in IR's intellectual histories. Her absolute exclusion reflects hierarchies even within unstated criteria for entry into IR's canon. Semple fails on very few of the unstated criteria, other than those assuming the derivative status of women's work. Suttner fails on more, since she challenges assumptions about the genre and substance of international thought. Cooper fails absolutely not only because her work is already known to be less significant than her male contemporaries, or because she was not integrated into privileged circles of knowledge production, but because she violated the gendered, civilizational and Eurocentric assumptions that dominated the emergence of academic IR (May 2021). For Cooper, the world from perspective of those victimized by classed, gendered and racialized hierarchies was the story of international relations. This could not fit with IR's account of itself from the mid-twentieth century, where the Peace of Westphalia but not colonialism and slavery, and the actions of great powers and great men, but not of the dispossessed, dictated the content of IR.

\section{Conclusion}

Birthed by Stawell's The Growth of International Thought, the existing study of canonical thinkers in IR is the study of the passage of ideas between fathers and sons, brothers, male friends and rivals. Like much work in Political Theory, IR's existing canon accounts only for 'constitutive relations of descent and influence between [white] men' (Nye, 1994: xiv; Sedgewick, 1985). This is confirmed, rather than contradicted, by the inclusion of six historical women in the existing canon. All European or North American, White or Ashkenazi Jewish, 
Arendt, Woolf, Sontag, Mead, Strange, and de Beauvoir belatedly appear as either anomalous and extraordinary, feminist, or inventors of their own field. As Joanna Russ observed in a different context, these 'women burst into the official canon as if from nowhere - eccentric, peculiar, with techniques that look odd and preoccupations that don't "fit"' (1983: 122).

But what follows from this? As we noted above, previous feminist interrogations of the canons in Political Theory and Philosophy have suggested different kinds of response (Tyson 2018: xxix). One recovers work that the canon rendered invisible, thus enabling fresh intellectual engagement with texts from the past (Waithe 1987-1995). Another reconstitutes the canon, either by holding the existing canon to its stated criteria (Greene 2014), altering the criteria, for example, the requirements of genre (Gardner 2003), or by focusing on intellectual foremothers rather than fathers (Weiss 2009). A third response rejects the idea of a canon as a set of individual authorities dealing with perennial disciplinary questions (Stuurman 2000: 160$165)$.

In our view, there is some merit in each of these responses, understood as strategies for reading the past, gaining insight into the present, and revising IR's disciplinary identity. Although Semple, Suttner and Cooper were not unknown outside IR, the recovery of their texts and ideas for IR is valuable for its historical and theoretical understanding. Not only do all three cast light on the mechanisms through which ideas about international relations move in specific historical contexts, they also enrich our thinking of the present, whether in terms of the relation between international politics and material environment, the micro and macro practices of militarism, or the centrality of racial, class and gendered hierarchies in contemporary world order.

In terms of reconstituting the canon, we do not think that it is possible to 'unbias' the canon by simply applying its criteria fairly to those excluded. The likely outcome is that privileged white women would receive recognition at the expense of those whose work does 
not fit existing assumptions about genre (books and essays in the form of linear arguments), standpoint (Eurocentrism) and authorship (individual) (Gardner 2003; Tyson 2018; Forestal and Philips 2018). Neither do we think that identifying an alternative women's 'tradition' of international thought is the answer. To analyze historical women is not to constitute a tradition of international thought. There is no such thing. Women's intellectual work is produced and received within multiple axes of hierarchy, which alongside the sheer numbers of women, mitigates against the commonality of experience and ideas needed to constitute a 'tradition' (Collins 1998; Bay et. al. 2015; Tyson 2018). Indeed, there is also no such thing as men's international thought, but there is Anglo-American white men's international thinking, which created and largely forms IR's canon.

Therefore, perhaps the appropriate response to the all-male, all-white canon is to reject canons altogether. As others have pointed out, there are serious risks in elevating 'great' figures. It reproduces problematic assumptions about 'originality' and the heroic character of intellectual work (Condren 1985; Carroll 1990). It neglects the informal intellectual work of figures who are 'canon-adjacent' or 'wives of the canon', collaborators who were central to the production of the 'great' texts and men (Forestal and Philips 2018: 588). Here methodological concerns from intellectual history join forces with feminist challenges to the idea that international thought can be equated with the texts of great thinkers (Stuurman 2000: 148). Instead our attention is redirected to political contexts, ideologies, discourses, institutions and collaborations in telling the story of the development of international thought.

Nonetheless, we have two concerns about simply endorsing the rejection strategy. First, although revisionist histories tell much more complex stories about the development of international thought, and introduce many new figures, they still work through tracing the ideas of particular individuals and groups. To date, this work continues to reproduce the gendered exclusions of the traditional canon. To date, women have never been at the forefront of 
revisionist histories. We saw this in Semple's disappearance from the story of the 1917 Inquiry, the marginalization of Semple and Suttner in tracing Eurocentrism and racism in international thought, and in Cooper's absence in re-readings of race and racism in world politics. Even when intellectual historians have sought to remedy women's absence, their work is conflated with feminism (Stöckmann 2017). If we do not pay specific attention to women's writing, and its full range, then it simply disappears or is recognized only highly selectively.

Secondly, the increasing sophistication and breadth in scholarship on the history of international thought has not fundamentally changed the importance of the canon and of 'traditions' in the reproduction of IR's disciplinary identity. Almost every IR student is still introduced to the subject through the analysis of texts from Thucydides to Waltz, often through the anthologies of international thought analyzed above, and often with specific reference to the period from the late nineteenth to the early-twentieth centuries in which our three putative canonical women worked. This is why we cannot abandon the strategy of reconstituting the canon altogether. Making a claim for historical women's texts, and in so doing challenging stated and unstated criteria of canonic inclusion, is a way of revisioning the history and scope of the IR discipline itself (Owens, Rietzler, Hutchings, Dunstan, 2021).

Therefore, future research agendas on international thought should combine elements of recovery, rejection and reconstitution. In our view, reconstituting the IR canon is about an ongoing process of unsettling, where the criteria for inclusion and exclusion are constantly in question. In this process, the recovery of women's ideas is important not to inaugurate women from the past as a new set of 'greats' addressing perennial questions, but to recognize their central place in the history of international thought and in providing resources for thinking about international relations in the present. 


\section{References}

Adams, Ellen E. 2014. 'Imperial Romances: travels in Japan with Ellen Churchill Semple and Fannie Cauldwell Macauley', The Journal of the Gilded Age and Progressive Era 13(2), 145151

Agnew, J. 2003. Geopolitics: Revisioning World Politics. London: Routledge

Anievas, Alex, Nivi Manchanda, and Robbie Shilliam (eds.) 2014. Race and Racism in International Relations: Confronting the Global Colour Line. London: Routledge

Ashworth, Lucian M. 2010. 'Realism and the Spirit of 1919: Halford Mackinder, geopolitics and the reality of the League of Nations', European Journal of International Relations, 17(2), 279-307

Ashworth, Lucian M. 2011. 'Feminism, War and the Prospects for International Government: Helena Swanwick (1864-1939) and the Lost Feminists of Interwar International Relations', International Feminist Journal of Politics, 13(1), 24-42

Ashworth, Lucian M. 2013. 'Mapping a New World: Geography and the Interwar Study of IR', International Studies Quarterly, 57, 138-49.

Ashworth, Lucian M. 2014. A History of International Thought. From the Origins of the Modern State to Academic IR. London: Routledge 
Ashworth, Lucian M. 2020. 'From Emulation to Enmity: The Changing View of Germany in Anglo-American Geopolitics' in Jens Steffek and Leonie Holthaus (eds.) 2020 Prussians, Nazis and Peaceniks: Changing Images of Germany in International Relations (Manchester: Manchester University Press

Bay, Mia, Farah J. Griffin, Martha S. Jones, and Barbara D. Savage (eds.) 2015. Toward an Intellectual History of Black Women. Chapel Hill: University of North Carolina Press

Bell, Duncan. 2018. 'Pragmatism and Prophecy: H. G. Wells and the Metaphysics of Socialism', American Political Science Review, 112(2), 409-422

Berman, M. 1974. 'Sex Discrimination and Geography: the case of Ellen Churchill Semple', Professional Geographer, 26, 8-11

Black, Jeremy. 2016. Geopolitics and the Quest for Dominance. Bloomington, IN: Indiana University Press

Blain, Keisha N., and Tiffany M. Gill (eds.) To Turn the Whole World Over: Black Women and Internationalism. Chicago, IL: University of Illinois Press, 2019

Bliddal, Henrick, Casper Sylvest, and Peter Wilson (eds.). 2013. Classics of International Relations: Essays in Criticism and Appreciation. London: Routledge

Broad, Jacqueline, and Green, Karen. 2009. A History of Women's Political Thought in Europe, 1400-1700. Cambridge: Cambridge University Press 
Brown, Chris, Terry Nardin, and Nicholas Rengger (eds.). 2002. International Relations in Political Thought. Cambridge: Cambridge University Press

Buckle, Henry. 1872. History of Civilization in England Volumes I-III. London: Longmans, Green \& Co.

Bushong, Allen D. 1975. 'Women as Geographers: some thoughts of Ellen Churchill Semple', Southeastern Geographer 15(2): 102-109

Bushong, Allen D. 1984. 'Ellen Semple Churchill 1863-1932', Geographers:

Biobibliographical Studies, Vol.8, Thomas W. Freeman (ed.). London: Mansell, 87-94

Carroll, Berenice. 1990. "The Politics of "Originality": Women and the Class System of the Intellect', Journal of Women's History 2 (2): 136-63

Chapman, Bert. 2011. Geopolitics: A Guide to the Issues. Santa Barbara: Praeger

Clark, Ian and Neumann, Iver B. (eds). 1996. Classical Theories in International Relations London: Macmillan

Clinton, David. 2003. Tocqueville, Lieber, and Bagehot: Liberalism Confronts the World London: Palgrave 
Cochran, Molly. 2017. 'The "Newer Ideals" of Jane Addams's Progressivism: A Realistic Utopia of Cosmopolitan Justice', in Molly Cochran and Cornelia Navari (eds.) Progressivism and US Foreign Policy Between the World Wars. New York: Palgrave Macmillan. pp.143165

Collins, Patricia Hill. 1998. Black Feminist Thought: Knowledge, Consciousness, and the Politics of Empowerment. London: Routledge

Condren, Conal. 1985. The Status and Appraisal of Classic Texts: An Essay on Political Theory, Its Inheritance and the History of Ideas. Princeton NJ: Princeton University Press Cooper, Anna J. 1988a [1925] Slavery and the French Revolutionists (1788-1805). Lewiston and Queenstown: Edwin Mellen

Cooper, Anna J. 1988b [1892] A Voice from the South. Oxford: Oxford University Press

Cooper Anna J. 1998 [1925] 'Equality of Races and the Democratic Movement', in Charles Lemert and Esme Bhan (eds.) The Voice of Anna Julia Cooper. Lanham MA: Rowman and Littlefield: $291-298$

Crampton, Jeremy W. 2006. 'The Cartographic Calculation of Space: race mapping and the Balkans at the Paris Peace Conference of 1919', Social and Cultural Geography, 7(5): 73152 
Crenshaw, Kimberlé (1989) 'Demarginalizing the Intersection of Race and Sex: A Black Feminist Critique of Antidiscrimination Doctrine, Feminist Theory and Antiracist Politics', University of Chicago Legal Forum, 1989(1): 139-167

Dodds, Klaus. 2014. Geopolitics: A Very Short Introduction. Oxford: Oxford University Press

Edkins, Jenny, and Nicholas Vaughn-Williams. 2009. Critical Theorists and International Relations. London: Routledge

Elman, Colin. 2014. The Realism Reader London: Routledge

European Economic and Social Committee. 2012. Bertha Von Suttner. EU Publications: < $\underline{\text { https://publications.europa.eu/en/publication-detail/-/publication/c77e2d1a-9a94-4696-ba9f- }}$ 3ab332881e90/language-en> (accessed March 23, 2020)

Fettweis, Christopher J. 2015. 'On Heartlands and Chessboards: classical geopolitics, then and now', Orbis, 59(2): 233-248.

Forestal, Jennifer and Menaka Philips. 2018. 'Gender and the "Great Man": Recovering Philosophy's "Wives of the Canon", Hypatia, 33(4): 587-592

Forsyth, M.G., H.M.A. Keens-Soper and P. Savigear (eds.). 1970. The Theory of International Relations: Selected Texts from Gentili to Treitschke. London: Routledge 
Fujii, Lee Ann (2017) 'The real problem with diversity in political science', Duck of Minerva, April 27, <http://duckofminerva.com/2017/04/the-real-problem-with-diversity-inpolitical-science.html> (accessed March 23, 2020)

Gabel, Leona C. 1982. From Slavery to the Sorbonne and Beyond: the life and writings of Anna Julia Cooper. Northampton MA: Smith College Studies in History, Vol. XLIX

Gardner, Catherine Villaneuva. 2003. Women Philosophers: Genre and the Boundaries of Philosophy. Boulder CO: Westview Press

Gelfand, Lawrence E. 1963 The Inquiry: American Preparations for Peace, 1917-19. New Haven: Yale University Press

Green, Karen. 2014. A History of Women's Political Thought in Europe, 1700-1800. Cambridge: Cambridge University Press

Guilhot, Nicolas (ed.) 2011. The Invention of International Relations Theory: Realism, the Rockefeller Foundation, and the 1954 Conference on Theory. New York: Columbia University Press

Gunnell, John G. 1993. The Descent of Political Theory: the Genealogy of an American Vocation. Chicago and London: Chicago University Press

Guy-Sheftall, Beverley. 2009. 'Black Feminist Studies: the case of Anna Julia Cooper', African American Review, 43(1), 11-15 
Hansen, Lene. 2011. 'A Research Agenda on Feminist Texts and the Gendered Constitution of International Politics in Rebecca West's Black Lamb and Grey Falcon', Millennium, 40(1), $109-28$

Hawley, Arthur J. 1968. 'Environmental Perception: Nature and Ellen Churchill Semple', Southeastern Geographer, 8: 54-59

Henderson, Errol A. 2017. 'The Revolution Will Not Be Theorised: Du Bois, Locke, and the Howard School's Challenge to White Supremacist IR Theory', Millennium, 45(3): 492-510

Hobson, John M. 2012. The Eurocentric Conception of World Politics: Western International Theory 1760-2010. Cambridge: Cambridge University Press

Huber, Valeska, Tamson Pietsch, and Katharina Rietzler. 2019. 'Women's International Thought and the New Professions, 1900-1940', Modern Intellectual History, First View, 1-25

Herren, Madeleine. 2016. 'Gender and International Relations through the lens of the League of Nations (1919-1945)' in Glenda Sluga and Carolyn James (ed.) Women, diplomacy and international politics since 1500. New York: Routledge, 182-201

Hutchings, Kimberley (2009) 'Simone de Beauvoir’ in Edkins \& Vaughan-Williams (eds.) Critical Theorists and International Relations. New York: Routledge, 66-76 Jahn, Beate (ed.) 2006. Classical Theory in International Relations. Cambridge: Cambridge 
University Press

James, C.L.R. 1963. The Black Jacobins: Toussaint L'Ouverture and the San Domingo Revolution. New York: Vintage

James, Joy. 2007. 'Profeminism and Gender Elites: W.E.B. Du Bois, Anna Julia Cooper and Ida B. Wells Barnett', in Susan Gillman and Alys Eve Weinbaum (eds.) Next to the Color Line: Gender, Sexuality and W.E.B. Du Bois. Minneapolis: University of Minnesota Press, 69-95

Kauppi, Mark V. and Viotti, Paul R. 1992 The Global Philosophers: World Politics in Western Thought. New York: Lexington

Keighren, Innes. 2010. Bringing Geography to Book: Ellen Semple and the Reception of Geographical Knowledge. London: I.B. Tauris

Kinsella, Helen M. 2014. 'Simone Weil: An Introduction', in Felix Rösch (ed.) Émigré Scholars and the Genesis of American International Relations: A European Discipline in America? London: Palgrave, 176-197

Koelsch, William A. 2014. 'Miss Semple meets the Historians: the failed AHA 1907 Conference on Geography and History and What Happened Afterwards', Journal of Historical Geography 45: 50-58. 
Knutsen, Torbjorn L. 1997 A History of International Relations Theory. 2nd ed. Manchester: Manchester University Press

Knutsen, Torbjorn L. 2015. 'Halford J. Mackinder, Geopolitics, and the Heartland Thesis', The International History Review 36(5): 835-57

Lebow, Richard Ned, Peer Schouten, and Hidemi Suganami (eds.) 2016. The Return of the Theorists: Dialogues with Great Thinkers in International Relations. London: Palgrave

Lemert, Charles and Bhan, Esme (eds.) 1998 The Voice of Anna Julia Cooper. Lanham MA: Rowman and Littlefield

Long, David, and Peter Wilson (eds.) 1995. Thinkers of the Twenty Years Crisis: Interwar Idealism Reassessed. Oxford: Clarendon

Luard, Evan. 1992. Basic Texts in International Relations: The Evolution of Ideas about International Society. London: Macmillan

Maliniak, Daniel, Ryan M. Powers, Barbara F. Walter. 2013. 'The Gender Citation Gap in International Relations,' International Organization 67(4): 889-922

May, Vivienne M. 2007. Anna Julia Cooper, Visionary Black Feminist: A Critical Introduction. London: Routledge 
May, Vivienne M. 2021. ‘Anna Julia Cooper on slavery’s afterlife: Can international thought “hear" her 'muffled” voice and ideas?' in Patricia Owens and Katharina Rietzler (eds). Women's International Thought: A New History. Cambridge: Cambridge University Press

Ménage, Gilles. 1984. The History of Women Philosophers (trans. Beatrice H. Zedler) Lanham, NY: University Press of America

McAlister, Linda Lopez (ed.) 1996. Hypatia's Daughters: Fifteen Hundred Years of Women Philosophers. Bloomington, IN: Indiana University Press

McCourt, David M. 2017. 'The Inquiry and the Birth of International Relations 1917-19', Australian Journal of Politics and History, 63(3), 394-405

Moody-Turner, Shirley. 2009. 'Preface to Special Section on Anna Julia Cooper', African American Review, 43(1), 7-9

Moody-Turner, Shirley and Stewart, James. 2009. 'Gendering Africana Studies: Insights from Anna Julia Cooper', African American Review, 43(1), 35-44

Moore, Cerwyn and Chris Farrands (eds.) 2010. International Relations Theory and Philosophy: Interpretive Dialogues. London: Routledge

Morgenthau, Hans J., and Kenneth W. Thompson (eds.) 1950. Principles and Problems of International Politics: Selected Readings New York: Knopf 
Nye, Andrea. 1994. Philosophia: The Thought of Rosa Luxemburg, Simone Weil, and Hannah Arendt. London: Routledge

Olson, William C., and A.J.R. Groom. 1991. International Relations: Then and Now: Origins and Trends in Interpretation. London: HarperCollins

Owens, Patricia. 2007. Between War and Politics: International Relations and the Thought of Hannah Arendt. Oxford: Oxford University Press

Owens, Patricia. 2018. 'Women and the History of International Thought', International Studies Quarterly, 62(3): 467-481

Owens, Patricia, and Katharina Rietzler (eds.). 2021. Women's International Thought: A New History. Cambridge: Cambridge University Press

Owens, Patricia, Katharina Rietzler, Kimberley Hutchings, Sarah Dunstan (eds.) 2021. Women's International Thought: Towards a New Canon. Cambridge: Cambridge University Press

Philips, Menaka. 2018. 'The Beloved and Deplored Memory of Harriet Taylor Mill: Rethinking Gender and Intellectual Labor in the Canon', Hypatia, 33 (4): 626-642

Pellow, David W. H. 1997. 'Anna J. Cooper: The International Dimensions', in Dolan Hubbard (ed) Recovered Writers/ Recovered Texts: Race, Class and Gender in Black Women's Literature. Knoxville: University of Tennessee Press, 60-74 
Peter, Simone. 2012. 'Bertha Von Suttner (1843-1914)', Oxford Handbook of International Law. Oxford: Oxford University Press, 1142-1145

Pollock, Griselda. 1999. Differencing the Canon: Feminism and the Histories of Art. London: Routledge

Richardson Keller, Frances. 1975. 'The Perspective of a Black American on Slavery and the French Revolution', Proceedings of the Third Annual Meeting of the Western Society for French History December 4-6, 1975, 165-176

Roache, Steven. 2008. Critical Theory and International Relations: A Reader. London: Routledge

Russ, Joanna. 1983. How to Suppress Women's Writing. London: Women's Press

Schmidt, Brian C. 1998. The Political Discourse of Anarchy: A Disciplinary History of International Relations. Albany: State University of New York Press

Sedgewick, Eve Kosofsky. 1985. Between Men: English Literature and Male Homosocial Desire. New York: Columbia University Press

Semple, Ellen C. 1909. 'The Operation of Geographic Factors in History', Bulletin of the American Geographical Society 41(7): 422-439 
Semple Ellen C. 1911. Influences of Geographic Environment: on the basis of Ratzels' system of anthropo-geography London: Constable \& Co.

Semple, Ellen C. 1913. 'Japanese Colonial Methods', Bulletin of the American Geographical Society, 45(4): 255-75

Semple, Ellen C. 1932. The Geography of the Mediterranean Region: its Relation to Ancient History. London: Constable \& Co.

Shilliam, Robbie. 2006. 'What about Marcus Garvey? Race and the Transformation of Sovereignty Debate', Review of International Studies, 32(3): 379-400

Sluga, Glenda. 2017. 'Women, Feminisms, and Twentieth-Century Internationalisms' in Internationalism: A Twentieth-Century History, edited by Glenda Sluga and Patricia Clavin. Oxford: Oxford University Press, pp.61-84

Smith, Hilda L. 2007. 'Women Intellectuals and Intellectual History: Their Paradigmatic Separation', Women's History Review, 16, 353-68

Smith, Hilda L., and Bernice A. Carroll (eds.) 2000. Women's Political and Social Thought: An Anthology. Bloomington: University of Indiana Press

Smith, Neil. 2003. American Empire: Roosevelt's Geographer and the Prelude to Globalization. Berkeley: University of California Press 
Stawell, F. Melian. 1929. The Growth of International Thought. London: Butterworth

Stöckmann, Jan. 2018. 'Women, Wars, and World Affairs: Recovering Feminist International Relations, 1915-39', Review of International Studies 44(2), 215-235

Stuurman, Siep. 2000. 'The Canon of the History of Political Thought: Its Critique and a Proposed Alternative', History and Theory, 39: 147-166

Suttner, Bertha v. 1894. Lay Down Your Arms. London: Longmans, Green \& Co.

Suttner Bertha v. 1903 Marthas Kinder. Dresden and Leipzig: C. Pierson.

Suttner, Bertha v. 1910a. Memoirs: records of an eventful life Volume I. Boston: Ginn \& Co.

Suttner, Bertha v. 1910b. Memoirs: records of an eventful life Volume II. Boston: Ginn \& Co.

Suttner, Bertha v. 1914. When Thoughts will Soar: a Romance of the Future. London: Constable \& Co.

Suttner, Bertha v. 2016 [1912] The Barbarization of the Skies (edited by Hope Elizabeth May) Mount Pleasant: Bertha v Suttner Project.

Tate, Merze. 1942. The Disarmament Illusion: The Movement for a Limitation of Armaments to 1907. New York: Macmillan 
Thakur, Vineet, and Peter Vale. 2020. South Africa, Race and the Making of International Relations. London: Rowman and Littlefield

Thompson, Kenneth W. 1982. Masters of International Thought. Baton Rouge: Louisiana State University Press

Thompson, Kenneth W. 1994. Fathers of International Thought: The Legacy of Political Theory. Baton Rouge: Louisiana State University Press

Tickner, J, Ann and Jacqui True. 2018. 'A Century of International Relations Feminism: From World War I Women's Peace Pragmatism to the Women, Peace and Security Agenda', International Studies Quarterly, 62(2): 221-233

Tully, James. Ed. 1989. Meaning and Context: Quentin Skinner and his Critics. Princeton NJ: Princeton University Press

Tyson, Sarah. 2018. Where are the Women?: Why Expanding the Archive Makes Philosophy Better. New York: Columbia University Press

van de Haar, Edwin. 2009. Classical Liberalism and International Relations Theory. London: Palgrave

Vasquez, John A. 1995 Classics of International Relations (3 ${ }^{\text {rd }}$ edition) New York: Pearson Veregerio, Claire. 2019. 'Context, Reception, and the Study of Great Thinkers in 
International Relations', International Theory 11: 110-137

Vitalis, Robert. 2015. White World Order, Black Power Politics: The Birth of American International Relations. Ithaca, NY: Cornell University Press

Waithe, Mary Ellen 1987-1995. A History of Women Philosophers in Four Volumes. Cleveland: Springer

Waithe, Mary Ellen. 2015. 'From Canon Fodder to Canon-Formation: How do we get There from Here', The Monist 98: 21-33

Weiss, Penny A. 2009. Canon Fodder: Historical Women Political Thinkers. University Park: Pennsylvania University Press

Wight, Martin. 2004. Four Seminal Thinkers in International Theory: Machiavelli, Grotius, Kant, and Mazzini. Oxford: Oxford University Press

Williams, Howard, Moorhead Wright, and Tony Evans (eds.) 1993. A Reader in International Relations and Political Theory. Buckingham: Open University Press

Wilson, Peter. 1995. 'Introduction: The Twenty Years' Crisis and the Category of "Idealism" in International Relations' in David Long and Peter Wilson (eds.) Thinkers of the Twenty Years Crisis: Interwar Idealism Reassessed. Oxford: Clarendon: 1-24 
Wilson, Peter. 2013. 'Attacking Hitler in England: patriarchy, class and war in Virginia Woolf's Three Guineas' in Hennik Bliddal, Casper Sylvest, and Peter Wilson (eds.) Classics of International Relations: Essays in Criticism and Appreciation. London: Routledge: 36-47

Witt, Charlotte. 2006. 'Feminist Interpretations of the Philosophical Canon', Signs: journal of women, culture and society, 31 (2): 537-552

Wolfers, Arnold and Laurence W. Martin (eds.) 1956. The Anglo-American Tradition in Foreign Affairs: Readings from Thomas More to Woodrow Wilson. New Haven: Yale University Press

Youde, Jeremy and Steele, Brent. 2018. "“Canon” Fodder: the Founding Fathers, Classics and “Isms" of International Relations' in Andreas Gofas, Innana Hamatu-Ataya and Nicholas Onuf (eds.) Sage Handbook of the History and Sociology of International Relations. London: Sage: $208-221$

Zerilli, Linda. 2008. 'Feminist Theory and the Canon of Political Thought' in John S. Dryzek, Bonnie Honig and Anne Phillips (eds) Oxford Handbook of Political Theory. Oxford: Oxford University Press: 106-124 